\title{
EXPRESSION OF THE CO-STIMULATORY RECEPTOR SLAMF-1 IN LYMPHOCYTES FROM PATIENTS WITH \\ AUTOIMMUNE THYROIDITIS
}

SAMPEDRO-NÚÑEZ $M^{1}{ }^{1}$, VITALES-NOYOLA $M^{2}{ }^{2}$, SERRANO-SOMAVILLA A ${ }^{1}$, DI PASQUALE CARMELINA ${ }^{3}$, HERNÁNDEZ-MARTÍNEZ REBECA ${ }^{1}$, RAMOSLEVI A ', GONZÁLEZ-AMARO $R^{2}$, MARAZUELA M

${ }^{1}$ Department of Endocrinology, Hospital Universitario de la Princesa, Instituto de Investigación Sanitaria Princesa, Universidad Autónoma de Madrid, Madrid, Spain ${ }^{2}$ Department of Immunology, School of Medicine, UASLP, San Luis Potosí, SLP, México ${ }^{3}$ Section of Endocrinology \& Internal Medicine, Dept. of Medical Sciences, University of Ferrara, Italy.

\section{INTRODUCTION}

Signalling lymphocytic activation molecule SLAMF1 (CD150) is a modulatory receptor expressed in most immune cells. Different data indicate that CD150 is involved in T cell cytokine production, NK cell and CD8 T cell mediated cytotoxicity, and T regulatory (Treg) cell activity.
Patients with autoimmune thyroid disease (AITD) show defects in their immune-regulatory mechanisms. Herein we assessed the expression and function CD150 in lymphocytes subpopulations from patients with AITD.

\section{PATIENTS AND METHODS}

We analyzed by multi-parametric flow cytometry and immunofluorescence techniques the expression of SLAMF1 in peripheral blood from 28 patients with autoimmune thyroid disease (AITD) and 21 controls, and thyroid tissue cell infiltrates from 5 patients. We also assessed the functional role of SLAMF1 in CD4+CD25+ Treg cells, using an assay of inhibition of cellular proliferation

\section{RESULTS}

Table 1:

General description of patients and controls
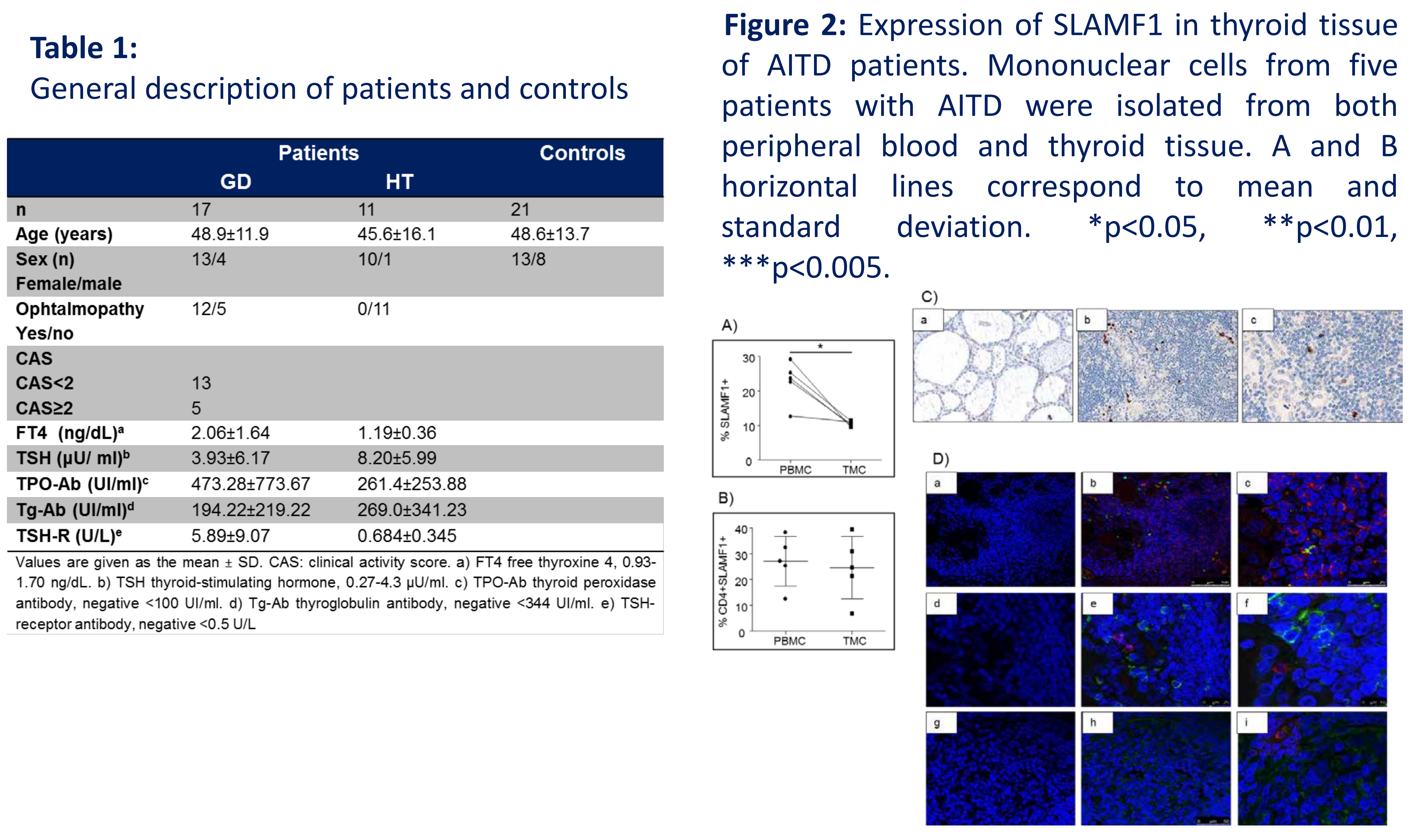

Figure 1: Expression of SLAMF1 in lymphocytes from patients with AITD. PBMC from 28 AITD patients and 21 controls were isolated and stained with mAbs directed against CD4, CD8, CD19, CD56, CD16, CD25, Foxp3, IL-17 and SLAMF1. B and E horizontal lines correspond to mean and standard deviation and A, C, D, F-H correspond the median and Q1-Q3. ${ }^{*} \mathrm{p}<0.05,{ }^{* *} \mathrm{p}<0.01$, $* * * p<0.005$.
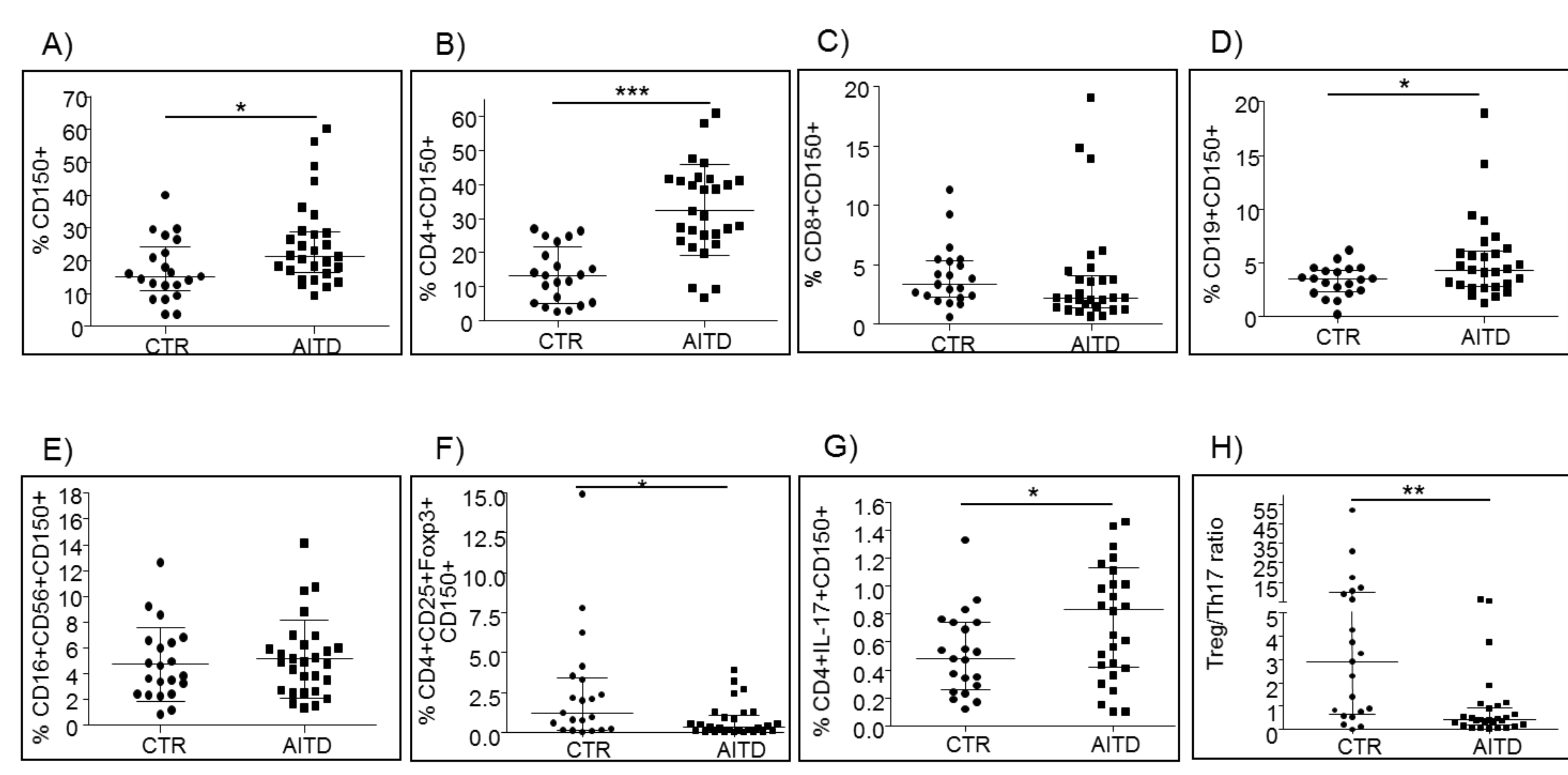

Figure 3: Suppressor function of CD25+ Treg cells in AITD patients. PBMC from 13 AITD patients (8 GD and 5 HT patients) and 14 healthy individuals were separated in CD25+ and CD25-, co-cultured, and added CFSE for 5 days. Then, cell proliferation was assessed by flow cytometry. $\mathrm{C}$ horizontal lines correspond to mean and standard deviation. ${ }^{*} \mathrm{p}<0.05,{ }^{* *} \mathrm{p}<0.01, * * * \mathrm{p}<0.005$
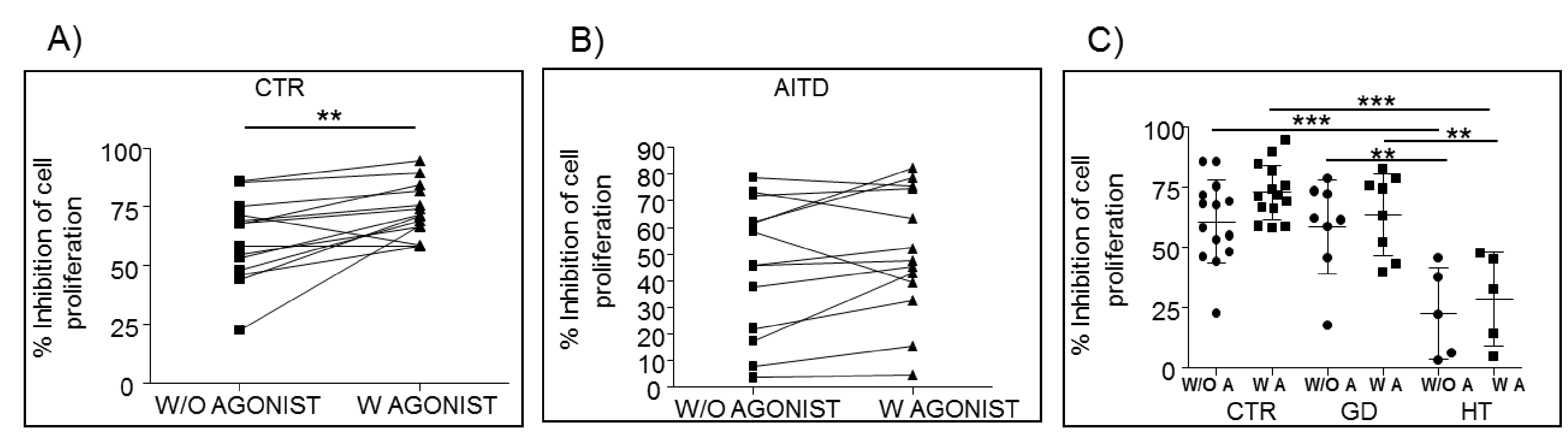

\section{CONCLUSIONS}

The altered pattern of expression and the functional alteration of SLAMF1 found in patients with AITD suggests that SLAMF1 could be involved in the pathogenesis of AITD.

Keywords: SLAMF1, CD150, Autoimmune Thyroiditis, Graves' Disease, Hashimotos' Thyroiditis.

\section{REFERENCES}

J. R. Kim, S. O. Mathew, R. K. Patel, R. M. Pertusi and P. A. Mathew. Altered expression of signalling lymphocyte activation molecule (SLAM) family receptors CS1 (CD319) and 2B4 (CD244) in patients with systemic lupus erythematosus
Madhumouli Chatterjee. Increased expression of SLAM Receptors SLAMF3 and SLAMF6 in SLE T Lymphocytes promotes Th17 differentiation. J Immunol 2012; 188: 1206-1212

L Liñán-Rico, B Hernández-Castro, L Doniz-Padilla, $H$ Portillo-Salazar, L Baranda, ME Cruz-Muñoz, R González-Amaro Analysis of expression and function of the co-stimulatory recep
systemic lupus erythematosus (SLE). Lupus (2015) 24, 1184-1190 